\title{
SHOUT FOR FREEDOM TO CURSE AT THE KINGDOM: CONTRASTING THAI LĖSE MAJESTÉ LAW WITH UNITED STATES FIRST AMENDMENT FREEDOMS
}

\author{
Sukrat Baber* \\ I. INTRODUCTION
}

\section{A. Thai Lèse-majesté Law}

Lèse-majesté (or lese majesty) laws prohibit insults, defamation, and criticism towards royal sovereigns of States. ${ }^{1}$ In an age of rising transparency and fight for democracy, these laws are seldom enforced and seem to be disappearing in countries where they exist. ${ }^{2}$ However, Thailand's lèse majesté laws, more than 100 years after their implementation, ${ }^{3}$ are still strongly enforced-more than 400 cases came to trial between 2006 and 2011. ${ }^{4}$ To avoid reprimand, citizens must at all times be wary of their public or even private discussions and published works relating to Thailand's royalty. One need not look further than the codified law to understand the length and strength of its reach: Section 112 of the Thai Criminal Code states, "Whoever, defames, insults or threatens the King, the Queen, the Heir-apparent or the Regent, shall be punished with imprisonment of three to fifteen years."

* Sukrat Baber is a 2014 J.D. graduate of Indiana University Robert H. McKinney School of Law. Mr. Baber was inspired to write about this topic after he arrived in Thailand for an internship in the summer of 2012, and was advised that he was better off not speaking about the Thai king at all because almost any comment could be construed as insulting the revered king and cause social or legal issues.

1. See Criminal Code [Crim. C.] B.E. 2499 (1956), s. 112, amended by Crim. C. (No. 17), B.E. 2547 (2003) (Thai.); see also David Streckfuss, Kings in the Age of Nations: The Paradox of Lese-Majeste as Political Crime in Thailand, 37 Comp. Stud. Soc'y \& Hist. 445, 463 n.25 (1995) ("Rattana Utthaphan, a student who wrote a personal letter to the king asking him to abdicate and enter politics, and the late Anan Senaakhan, who made two speeches criticizing the Queen at Sanam Luang, were each given six years.").

2. See generally Streckfuss, supra note 1.

3. Thailand's King Pardons Swiss Man, BBC News (Apr. 12, 2007), http://news.bbc.co.uk/2/hi/asia-pacific/6547413.stm, archived at http://perma.cc/4TQR4BDH.

4. Todd Pitman \& Sinfah Tunsarawuth, Thailand Arrests American for Alleged King Insult, AssociATED PRESS (May 28, 2011), http://sg.news.yahoo.com/thailand-arrestsamerican-alleged-king-insult-073615032.html, archived at http://perma.cc/GL5R-LCKK.

5. CRIM. C. B.E. 2499 (1956), s. 112, amended by CRIM. C. (No. 17), B.E. 2547 (2003) (Thai.). 


\section{B. US First Amendment Freedoms}

The United States has unique free speech laws deriving from the First Amendment of the US Constitution. ${ }^{6}$ The rights of freedom of speech and freedom of expression are cornerstones of the democracy envisioned by the drafters of the Bill of Rights. ${ }^{7}$ They allow individuals to carry out peaceful protests in public venues without fear of government intervention, express opinions among friends and family without fear of the law, and publish virtually any work to the masses without fear of censorship. Unlike other developed countries, the United States does not categorically prosecute hate speech towards people or groups. ${ }^{8}$ Some commentators are concerned that allowing "freedom to hate" is problematic for moral and practical reasons (e.g., hateful publications inciting violence), but the Supreme Court has continued to protect such speech. ${ }^{9}$

\section{Near-Polar Opposites}

This Note first discusses the respective turbulent histories of Thai lèse-majesté law and US First Amendment freedoms. Case law and popular events are discussed to draw the timelines for each. Next, this Note looks at the issues the two countries and their laws present today. Throughout the historical narratives, this Note points to some theoretical inconsistencies and analyses the political and legal ramifications of the laws' developments. Special attention is placed on whether lèse-majesté law is anachronistically out of place and on the contours of protected hate speech in the United States. Then, this Note compares and contrasts the speech laws of the two nations. In particular, this Note argues that the two nations represent the extremes of freedom to speak out against power and cultural issues. Thai lèse-majesté law forbids inhabitants to speak critically of the country's

6. U.S. CONST. amend. I.

7. "[James] Madison proposed ... 'the people shall not be deprived or abridged of their right to speak, to write, or to publish their sentiments; and the freedom of the press, as one of the great bulwarks of liberty, shall be inviolable." Stewart Jay, The Creation of the First Amendment Right to Free Expression: from the Eighteenth Century to the MidTwentieth Century, 34 WM. Mitchell L. ReV. 773, 791 (2008) (quoting Madison Resolution (June 8, 1789), in Creating the Bill of Rights: The Documentary ReCord From the First Federal Congress 12 (Helen E. Veit, et al. eds., 1991)).

8. Frederick Schauer, The Exceptional First Amendment 8 (Harv. Univ., John F. Kennedy Sch. Gov't, KSG Faculty Research Working Papers Series, Paper No. RWP05-021, 2005).

9. Michael W. McConnell, You Can't Say That: 'The Harm in Hate Speech,' by Jeremy Waldron, N.Y. Times, (June 22, 2012) (book review), http://www.nytimes.com/2012/06/24/books/review/the-harm-in-hate-speech-by-jeremywaldron.html, archived at http://perma.cc/A8KS-WZWU. 
royalty. ${ }^{10}$ This Note will show that "criticism" as it relates to the law is defined very broadly, and breaching the law means years of incarceration. This law is contrasted by the near-unfettered First Amendment freedom to criticize anyone or voice any range of opinion privately and publicly, even when causing the listener great emotional distress. ${ }^{11}$ Ultimately, this Note argues that Thai lèse-majesté laws should borrow from First Amendment freedoms and effectively be repealed, but the different social and cultural dynamics of Thailand require a cautioned transition from the vices of lèsemajesté to a nation-wide discourse regarding the monarchy.

\section{HISTORY OF THAI LÈSE-MAJESTÉ LAW}

\section{A. Inception and Early Application}

The law of lèse-majesté in Thailand appeared in section 98 of the nation's first Criminal Code: "Whoever threatens, insults or defames the King, the Queen, the Crown Prince, or the Regent during the Regency, shall be punished with imprisonment not exceeding seven years and fine not exceeding five thousand ticals." " Although Thai lèse-majesté law seemed to go into a decline as of 1932 until the revision of the Code in $1957,{ }^{13}$ there was a notable case before the end of former decade in $1939 .{ }^{14} \mathrm{Paa}$ Huu'chonhua claimed to be a sorcerer or magician that could treat villagers' ailments through supernatural powers. ${ }^{15}$ He claimed that one of his powers was bringing the king and the constitution to his mercy. ${ }^{16}$ Charged with "telling a startling false-hood," he was sentenced to one year of imprisonment by the lower court. ${ }^{17}$ The High Court, however, ruled that his wording was "without ill intentions and did not aim to cause people to look down on or despise anyone." 18 Thus his wording was held as not violating lèse-majesté law. ${ }^{19}$ Since most of the cases to be discussed in this Note have resulted in guilty convictions, the case of Paa is noteworthy as an example (Thai.)

10. CRIM. C. B.E. 2499 (1956), s. 112, amended by CRIM. C. (No. 17), B.E. 2547 (2003)

11. See infra Part V.D.

12. Penal Code [Penal C.] R.S. 127, $\$ 98$ (Penal Code for the Kingdom of Siam (Draft Version) 1908), archived at http://perma.cc/D99K-8QH6; Thailand's King Pardons Swiss Man, supra note 3.

13. Streckfuss, supra note 1 , at 472.

14. Streckfuss, supra note 1, at 453 n.13.

15. Streckfuss, supra note 1, at 453 n.13.

16. Streckfuss, supra note 1, at 453 n.13.

17. Streckfuss, supra note 1 , at 453 n.13.

18. Streckfuss, supra note 1, at 453 n.13.

19. Streckfuss, supra note 1 , at 453 n.13. At least one commentator and advisor to the present Thai King believed that this decision would have gone the other way in today's Thai courts. Streckfuss, supra note 1, at 453 n.13. 
of a nuance that favored the defendant over the long arm of Thai lèsemajesté law.

The strength of the monarchy was jeopardized in 1932 when the Thai monarchy experienced an overthrow it barely survived..$^{20}$ But with the help of military matrons, it was able to undergo revitalization in the late $1950 \mathrm{~s}$, and the king "was able to emerge as perhaps the most enduring actor within Thai politics." 21 The Criminal Code's revision in 1957 has made lèsemajesté not just a crime against the representation of the monarchy, but an offense of national security, and with then-prime minister Sarit Thanarat's ${ }^{22}$ assistance (and similar assistance and loyalty of successive military dominated governments), lèse-majesté law has gained much significance. Contemporaneously, it has become a method of political and cultural subversion. $^{23}$

\section{B. Lèse-Majesté in the News and Political Speech}

Kosai Mungjaroen was one of the first victims of lèse-majesté subversion after the crime was deemed a national security offence. ${ }^{24} \mathrm{He}$ was speaking in July 1957 to a crowd of 200 at Sanam Luang, claiming to fairly report the news, and was arrested for lèse-majesté after mentioning the king. ${ }^{25} \mathrm{He}$ uttered that "the younger brother killed the older brother in order to seize the throne; playing with a gun caused the accident; and King Rama IX will abdicate in favor of his son and run in the elections." ${ }^{26}$ The prosecution argued that the wording was an insult to the king. ${ }^{27}$ The court agreed, pronouncing such words as "intentional" and "sought to bring discredit to the power, reputation, and honor of the king, in his revered position among the Thai people and as a result the king may become a subject of insult and hate among the people." 28

The punishment for a lèse-majesté offence in Thailand today, not less

20. See Streckfuss, supra note 1 , at 446.

21. Streckfuss, supra note 1 , at 446.

22. "The Thai army officer and Prime Minister Sarit Thanarat (1908-1963) overthrew the government of Phibun Songkhram in 1957 and was responsible for initiating major programs of economic development and social welfare." Encyclopedia of World Biography on Sarit Thanarat, BooK RAGS, http://www.bookrags.com/biography/saritthanarat/ (last visited Nov. 17, 2013, archived at http://perma.cc/RX4M-WA58).

23. Streckfuss, supra note 1, at 472.

24. Streckfuss, supra note 1, at 453; see also Peter Leyland, The Struggle for Freedom of Expression in Thailand: Media Moguls, the King, Citizen Politics and the Law, 2 J. MediA L. 115, 127 (2010).

25. Streckfuss, supra note 1 , at 454.

26. Streckfuss, supra note 1, at 454. (quoting Decision 51/2503 PKSD 2503 dau. 73, 7378 (1960) (Thai.)) (internal quotation marks omitted).

27. Streckfuss, supra note 1 , at 454 .

28. Streckfuss, supra note 1, at 454. 
than three and not more than fifteen years' imprisonment, was set in $1976 .^{29}$ Not only is the penalty arguably grievous in relation to the actual harm produced, but the possibility of a charge can surface for trivial, irreconcilable events. One example of this is the incident involving the Thai Rat. ${ }^{30}$ On December 12 of 1976, the Thai newspaper Thai Rat showed a picture of the crown prince's fiancée singing a song called "The Lao Moon" while standing between two Thai princesses who were playing instruments to compliment the singing. ${ }^{31}$ The celebration was of students soliciting money for a royal organization called the Sai Jai Thai Foundation. ${ }^{32}$ The next day, in a different part of the newspaper, there was a picture of a seemingly foreign woman feeding a dog next to a Lao musical instrument called a khaen. ${ }^{33}$ Days later, a group of locals contacted the police and pressed charges for lèse-majesté. ${ }^{34}$ Apparently, these individuals felt the picture compared the recent picture of the princesses to the dog in the newer picture, that it was a slanderous comparison between the crown prince's fiancée and the canine. ${ }^{35}$ The official charge, made by a pre-established group representing the village, claimed the symbolic comparison would "cause the people who read it to understand negatively about the institution of the monarchy." $" 36$ Thankfully, such a wild claim was not accepted by the police, but it gained much attention and was a concerning indication of how easily Thai lèse-majesté law can be provoked. ${ }^{37}$

Fast-forwarding to a 1986 provocation, a case surfaced that garnered much attention in the political sphere and among the general public. Wira Musikaphong was a democratic political candidate speaking in front of a Thai crowd in defense of a fellow party member whose stature as a representative of the people was questioned because he was born of a wealthy family in Bangkok. ${ }^{38}$ Mr. Musikaphong stated that birth place and

29. Streckfuss, supra note 1, at 472; CRIM. C. B.E. 2499 (1956), s. 112, amended by CRIM. C. (No. 17), B.E. 2547 (2003) (Thai.).

30. Streckfuss, supra note 1, at 457.

31. Streckfuss, supra note 1, at 457. In a similar incident: a Frenchman refused to turn off his reading light aboard Thai Airways when told that it was disturbing the Thai princess who was sitting in front of him. Wikileaks: U.S. Ambassador Boyce Offers Lese Majeste Advice, Political Prisoners IN Thailand (Sept. 3, 2011), https://thaipoliticalprisoners.wordpress.com/2011/09/03/wikileaks-u-s-ambassador-boyceoffers-lese-majeste-advice/, archived at http://perma.cc/9TXS-M4AN. His refusal was followed by a derogatory statement directed at the princess and his arrest for lèse-majesté once the flight landed in Bangkok. Id. The man was eventually acquitted after writing an apology letter to the king - then deported. Id.

32. Streckfuss, supra note 1 , at 457.

33. Streckfuss, supra note 1 , at 457.

34. Streckfuss, supra note 1 , at 457.

35. Streckfuss, supra note 1 , at 457.

36. Streckfuss, supra note 1 , at 457.

37. Streckfuss, supra note 1 , at 457.

38. Streckfuss, supra note 1 , at 449. 
status were poor measures for leadership:

If I could have chosen myself, why would I have chosen to have been born as a child of rice farmers in Songkhla? . . . If I could have chosen, I'd certainly have chosen to be born in the middle of the royal palace []. Then I would've been Prince [] Wira. I wouldn't have had to come out here and stand in the hot sun and speak to you all. At this time, noon, I would have gone into an air-conditioned room, eaten a bit, lain down to sleep, and then gotten up at three ... [but] one can't choose where one is born.

Later that day, in another speech, he restated:

If I were a prince now, I would not be standing here, speaking, making my throat hoarse and dry. Here it is 6:30. I would be drinking some intoxicating liquors to make myself comfortable and happy. Wouldn't that be better than standing here talking and completely tiring out my poor shin bones? ${ }^{39}$

An opposition party leader submitted the transcript of the speech to police and suggested the words constituted a lèse-majesté violation. ${ }^{40}$ Initially, there were no charges, and the ruckus did not stop the democrats from winning the election. ${ }^{41}$ But then, the opposition party pressed the issue to a trial court, and although the lower tribunal held there was no lèsemajesté violation, the appellate and high courts saw otherwise. ${ }^{42}$ The prosecution claimed that Wira spoke "with 'the intent of having the people lose their faith and respect' in the monarchy and of 'damag[ing] their royal honor and reputation,' causing the royalty to be 'looked down upon and hated." 43 This case illustrates that the political venue is particularly

39. Streckfuss, supra note 1, at 449-50 (quoting Somchai Jenchaijittarawaanit, Khadii prawatisaat minphraborom detchaanuphaap: Wiira Mutsikaphong tit khuk phrau' kaanmu'ang! [A Historic Case of Lèse-Majesté: Wira Mutsikaphong Jailed Because of Politics!] (Krungthep: Samnakngaan phu'a Sawaenghaa Khwaamyuttitham nai Sangkhom, 2531 [1988], 28-29, 35) (alterations added).

40. Streckfuss, supra note 1 , at 450.

41. Streckfuss, supra note 1, at 450.

42. Streckfuss, supra note 1, at 460.

43. Streckfuss, supra note 1, at 451 (quoting Somchai, Khadii, 83, 133-36, 155; Pramuan khamphiphaaksaa saan diikaa (PKSD) 2531 [Collection of the Decisions of the High Court, 1988] Decision 2354/2531 [1988], pp. 894, 904); see also Viewing Cable 08BANGKOK3398, Update on Lese Majeste Cases in Thailand, WiKiLEAKs (Nov. 18, 2008, 9:29 AM), http://wikileaks.org/cable/2008/11/08BANGKOK3398.html, archived at http://perma.cc/BF8Q-6C6P. 
susceptible to lèse-majesté accusations. It is hard to predict that two (likely) unrelated pictures, such as those in the Thai Rat case, could lead to a question of blasphemy to the royalty, but easier to do so in a race to gain political power where the competition could draw upon questionable allegiances for electoral advantage.

Public awareness of these cases has compelled publishing parties to take caution when mentioning royalty: many academic and other works "have used euphemisms such as 'establishment' in English or 'sathaban' (institution) in Thai to indicate who or what was being spoken about, enabling probing if cautious accounts of the palace." 44

Some legally conscious Thai scholars avoided the custom of using King Bhumibol's full title and called him "king" (kasat) instead. ${ }^{45}$ This created the impression of a less revered position for the monarchy, showing a counterproductive element to Thai lèse-majesté law. ${ }^{46}$ One scholar claimed that he avoided royal language "in a deliberate attempt to demystify the institution. ${ }^{, 47}$ Apparently some of the distancing from custom is for motives beyond avoiding criminal prosecution.

\section{BRIEF HISTORY OF US FIRST AMENDMENT FREEDOMS}

\section{A. Groundwork of the Founding Fathers}

The history of US First Amendment freedoms is long, rich, and fascinating. For purposes of this Note, only select cases and developments will be highlighted to touch on some of the defining moments, and paint a summarized picture of where the US was and where it is now with freedom of speech and freedom of expression laws deriving from the First Amendment.

The First Amendment states: "Congress shall make no law respecting an establishment of religion, or prohibiting the free exercise thereof; or abridging the freedom of speech, or of the press; or the right of the people peaceably to assemble, and to petition the government for a redress of grievances." 48

Former US President James Madison introduced the Bill of Rights to the first US Congress, which bill included free speech clauses but with different phraseology. ${ }^{49}$ After submitting multiple versions, the clause as it

44. See Michael K. Connors, When the Walls Come Crumbling Down: The Monarchy and Thai-style Democracy, 41 J. CONTEMP. Asia 657, 659 (2011).

45. Id. at 659-60.

46. Id. at 660 .

47. $I d$.

48. U.S. CONST. amend. I.

49. See Jay, supra note 7 and accompanying text. Another of Madison's amendments encompassed the rights of assembly and petition: "[t]he people shall not be restrained from 
stands today was adopted along with the rest of the Bill of Rights on August $21,1789 .^{50}$

The Sedition Act of 1798 prohibited criticism of the federal government or the president; specifically, it was illegal to:

write, print, utter or publish . . . any false, scandalous and malicious writing or writings against the government of the United States, or either House of the Congress . . . or the President ... with intent to defame ... or to bring them, or either of them, into contempt or disrepute; or to excite against them, or either or any of them, the hatred of the good people of the United States. ${ }^{51}$

Interestingly, the Act was never brought before the Supreme Court as inconsistent with the First Amendment. ${ }^{52}$ Madison and his fellow Republicans, however, vehemently denounced the Act as unconstitutional and enlarging congressional powers despite some of the inherent principles of the Bill of Rights, namely, free speech and states' rights. ${ }^{53}$ Logically, the fire was bound to burn out, though, as "[f]ederal sedition prosecutions disappeared with the expiration of the Sedition Act in 1801, and a few years later the Court held that federal courts had no constitutional authority to punish individuals for common law crimes, including sedition." 54

\section{B. Paranoia of Communists and the Espionage Act}

A recent observation of US Supreme Court cases between the Sedition Act and World War I shows that none of the cases related to the First Amendment dealt directly with the Amendment. ${ }^{55}$ It was not until

peaceably assembling and consulting for their common good; nor from applying to the legislature by petitions, or remonstrances for redress of their grievances." Jay, supra note 7 (quoting Madison Resolution (June 8, 1789), in CREATING THE BILl OF Rights: The DOCumentary ReCORD from the First Federal Congress 12 (Helen E. Veit, et al. eds., 1991)).

50. See Jay, supra note 7, at 791; Barry Adamson, Freedom of Religion, the First Amendment, and the Supreme Court: How the Court Flunked History 93 (2008).

51. Sedition Act of 1798, 1 Stat. 596 (1798).

52. See Jay, supra note 7 , at 794 .

53. See Jay, supra note 7, at 795-96.

54. See Jay, supra note 7, at 803; see also H. Jefferson Powell, Parchment Matters: A Meditation on the Constitution as Text, 71 IowA L. REV. 1427, 1434 (1986) ("Americans tested the Act's legitimacy not against legal tradition but against what the text itself seemed to say. How could the Sedition Act be consistent, these doubters asked, with a constitutional command that Congress 'make no law . . abridging the freedom of speech, or of the press?' Isn't a person less free to speak, for all practical purposes, if she can be fined or imprisoned if her speech insults the President or suggests that Congress is acting for selfish rather than patriotic goals?").

55. Jay, supra note 7 , at 803 . 
1917 and the Espionage Act that the issue of free expression was regularly considered on the bench. ${ }^{56}$ The first case in a series involving the Act implicated Charles T. Schenck, general secretary of the Socialist Party, and his wife Elizabeth Baer, who were convicted of violating the Espionage Act for distributing materials to men eligible for the draft. ${ }^{57}$ In short, the information condemned the war and condoned membership with the Socialist Party. ${ }^{58}$

The presiding Chief Justice of the Supreme Court, Oliver Holmes, writing for the majority and upholding the conviction, admitted that by themselves, the actions of the defendants were protected by the First Amendment; however, context can be controlling. ${ }^{59}$

The question in every case is whether the words used are used in such circumstances and are of such a nature as to create a clear and present danger that they will bring about the substantive evils that Congress has a right to prevent. It is a question of proximity and degree. When a nation is at war many things that might be said in time of peace are such a hindrance to its effort that their utterance will not be endured so long as men fight and that no Court could regard them as protected by any constitutional right. ${ }^{60}$

The mention of "clear and present danger," and the analogy that the most protective free speech provision "would not protect a man in falsely shouting fire in a theatre and causing a panic," ${ }^{, 61}$ would be seen time and again in US judicial history. ${ }^{62}$

Minnesota's version of the Espionage Act was particularly contentious regarding First Amendment challenges. ${ }^{63}$ Gilbert v. Minnesota resulted in a loss for First Amendment protections but not without strong dissent by Justice Brandeis - in fact, his dissent focused only on the First Amendment portions of the majority decision. ${ }^{64}$ The alleged violation was a man's passionate disagreement with President Wilson's claim that the War would make the United States more democratic. ${ }^{65}$ The man in violation of Minnesota's version of the Espionage Act stated:

56. See Jay, supra note 7 , at 803,814 , and 830 .

57. Schenck v. United States, 249 U.S. 49, 50 (1919).

58. Id. at 53 .

59. Id. at 52 .

60. Id. (emphasis added).

61. Id.

62. Jay, supra note 7 , at 836 .

63. Jay, supra note 7 , at 860 .

64. 254 U.S. 325, 331 (1920).

65. Id. at 327. 
Have you had anything to say as to whether we would go into this war? You know you have not. If this is such a good democracy, for Heaven's sake why should we not vote on conscription of men? We were stampeded into this war by newspaper rot to pull England's chestnuts out of the fire for her. I tell you if they conscripted wealth like they have conscripted men, this war would not last over fortyeight hours. ${ }^{66}$

Brandeis found the Act too broad. ${ }^{67}$ His reasons were that it held as violators those that civilly advised pursuit in affairs other than the military-for whatever reason. ${ }^{68}$ It would make a criminal out of parents, in the privacy of their own homes, who advised their children not to enlist in the army. ${ }^{69}$ Brandeis found the law stricter than the federal version, abridging freedom of speech and freedom of the press. ${ }^{70}$ The Act, he said, "aims to prevent, not acts, but beliefs.",

New York's Espionage Act may have been as broad as Minnesota's: the law forbade acts 'to 'advocate[]' anarchism or to 'advocate[], advise[], or teach[] the duty, necessity or propriety' of toppling the government by force or by assassination of officials." 72 In Gitlow v. New York, the manager of a left wing Socialist newspaper who advocated overthrowing the government through violent means was convicted under the Act and was found guilty by the Federal Supreme Court. ${ }^{73}$ The facts showed that despite a call to action in the newspaper, no uprisings resulted from the publication. ${ }^{74}$ Justice Sanford, writing for the majority, asserted that First Amendment freedoms are not absolute. ${ }^{75}$ They are limited where police powers must protect from dangers to the public welfare, corruption of public morals, and disturbances of the peace. ${ }^{76}$ Sanford found that the left wing Socialist press was not in the protected bubble of free speech. ${ }^{77}$

Justice Holmes' dissent, however, foreshadowed the future direction of the law. He used the clear and present danger analysis that he used to overrule First Amendment protection in Schenck to disagree with the conviction: "[T] here was no present danger of an attempt to overthrow the

66. Id.

67. Id. at 334-43.

68. Id. at 341 .

69. Id. at 335-36.

70. Id. at 341 .

71. Id. at 335 .

72. Jay, supra note 7, at 863 (quoting N.Y. PENAL LAW $\S 161$ (1909)).

73. 268 U.S. 652, 657-58 (1925).

74. Id. at 656 .

75. Id. at 666 .

76. Id. at 667 .

77. Id. at 668-69. 
government by force on the part of the admittedly small minority who shared the defendant's views. . . . [W] hatever may be thought of the redundant discourse before us it had no chance of starting a present conflagration."

Perhaps a bigger issue, however, was the indeterminateness of whether the First Amendment applied to states as well as the federal government. ${ }^{79}$ The jury was out on this issue, the majority gave it some mention but was vague on the matter, ${ }^{80}$ while Holmes had no doubt that through the Fourteenth Amendment Due Process clause, the First Amendment applied to the several states. ${ }^{81}$ Indeed, Gitlow marked the last time there was doubt of the applicability of the First Amendment freedoms to the states. ${ }^{82}$ In Near v. Minnesota, Chief Justice Evans made it clear that "it is no longer open to doubt that the liberty of the press and of speech is within the liberty safeguarded by the due process clause of the Fourteenth Amendment from invasion by state action." $" 83$

\section{Let's Talk Violence}

Despite the "loss" for the First Amendment in Gitlow, free speech freedoms would be celebrated and enforced by the Supreme Court in defining ways going forward. In Fiske v. Kansas, the Kansas Syndicalism Act "forbidding advocacy of violence as a means of effecting political or industrial change" was invoked to convict a man merely for the preamble of an Industrial Workers of the World document that factually stated the difference in material well-being between employers and employees. ${ }^{84}$ The majority opinion denied any advocacy of syndicalism as defined by the statute. ${ }^{85}$ This decision was the first to unanimously protect free speech on primarily constitutional grounds. ${ }^{86}$

The issue of inciting violence was contemplated in more micro circumstances too. In Cantwell v. Connecticut, a Jehovah's Witness was practicing his religious duties in a predominantly Catholic neighborhood whose residents were offended by recordings played by the young man. ${ }^{87}$ The recordings were described as "a general attack on all organized religious systems as instruments of Satan and injurious to man." ${ }^{88}$ One

\footnotetext{
78. Id. at 673; see also Schenck v. United States, 249 U.S. 49, 52 (1919).

79. Jay, supra note 7 , at 866 .

80. Gitlow, 268 U.S. at 666 n.9.

81. Id. at 672 .

82. Jay, supra note 7 , at 866 .

83. Near v. Minnesota, 283 U.S. 697, 707 (1931).

84. Jay, supra note 7, at 873; Fiske v. Kansas, 274 U.S. 380, 383 (1927).

85. Fiske, 274 U.S. at 386.

86. Jay, supra note 7 , at 873 .

87. 310 U.S. 296, 301 (1940).

88. Id. at 309 .
} 
group of potential converts wanted to hit the Jehovah's Witness - but the Witness made a run for it. ${ }^{89}$ At trial, he pleaded not intending to insult or incite violence in anyone, so the question was put: "were the words likely to provoke an immediate hostile response? Were the words 'profane, indecent, or abusive remarks directed to the person of the hearer?" 90 The judge thought not; Cantwell clarified that words alone are not necessarily conclusive in determining a clear and present danger, and it consequentially raised the bar for which words would be considered likely to incite violence. $^{91}$

Cantwell, coupled with the slew of cases limiting Communist Party affiliates, seemed to help religious and political minorities most in need of judicial advocacy by adding muscle to the First Amendment. Yet in the years following the Second World War, federal and state governments passed many laws and regulations restricting Communist membership and the outgrowths of such associations. ${ }^{92}$ As military tensions between the United States and the former Soviet Union grew, Communists again came under scrutiny. ${ }^{93}$

\section{Freedom of Association}

One case deriving from Communist affiliation was of Robel, a machinist at a Seattle shipyard, and an open Communist Party member who was convicted under the Internal Security Act's prohibition against members of Communist organizations in defense facilities. ${ }^{94}$ Robel should have resigned as a matter of law pursuant to the Secretary of Defense's determination that the shipyard was a defense facility. ${ }^{95}$ Chief Justice Warren, alongside the remaining five-member majority, refused to "accept at face value the government's assertion of 'national defense' as a justification for a law that "cut deeply into the right of association." ${ }^{\prime \prime 6}$ The panel rejected that the man was guilty by association alone - void of any actual threat to the government. ${ }^{97}$ Under this law, even someone aloof to illegal underpinnings of his or her political organizations could be prosecuted. ${ }^{98}$ Consistent with such judicial advocacy, the Warren court continued to strengthen the First Amendment's protection of associative

89. Id.

90. Jay, supra note 7, at 884 (quoting Cantwell, 310 U.S. at 309).

91. Cantwell, 310 U.S. at 310.

92. Jay, supra note 7, at 920-21.

93. Jay, supra note 7 , at 921 .

94. U.S. v. Robel, 389 U.S. 258, 260, 265 n.10 (1967).

95. Id. at 260 .

96. Jay, supra note 7, at 954-55 (quoting Robel, 389 U.S. at 264).

97. Robel, 389 U.S. at 266-268.

98. Id. at 266 . 
liberty through the 1960 s. $^{99}$

During this time, prosecution of Communists essentially came to a close, ${ }^{100}$ but alas, other expressions of association were under attack. Starting with (among others) the 1963 case of Edwards v. South Carolina, the civil rights movement was facing allegations of illegality relating to expression and association. ${ }^{101}$ In Edwards, members of a black church legally rallied to a public place and bore signs and chanted to denounce black segregation. ${ }^{102}$ Everything they were doing, the police agreed, was lawful. ${ }^{103}$ There was no incitement of any kind or anything that would have insulted passers-by. ${ }^{104}$ However, after some time, the police ordered them all to leave in fifteen minutes or there would be arrests based on state disturbance of peace statutes. ${ }^{105}$ The church members did not leave and mass arrests were made and fines given. ${ }^{106}$ The Supreme Court, ripe with free speech advocacy, reversed every last conviction. ${ }^{107}$ Justice Stewart proclaimed the First Amendment did "not permit a State to make criminal the peaceful expression of unpopular views." ${ }^{108} \mathrm{He}$ continued:

The circumstances in this case reflect an exercise of these basic constitutional rights in their most pristine and classic form. ... They peaceably assembled at the site of the State Government and there peaceably expressed their grievances "to the citizens of South Carolina, along with the Legislative Bodies of South Carolina."109

This strong language was arguably influential not only for development of First Amendment rights, but for the subsequent civil rights movement in the United States.

\section{E. Whose Side are You On? NAACP v. Claiborne Hardware}

Displays of pacifistic protest were also protected by courts that wielded the First Amendment as the sword to slay impediments to anti-war expression. ${ }^{110}$ But, turning back to race issues, there stands out a case whose

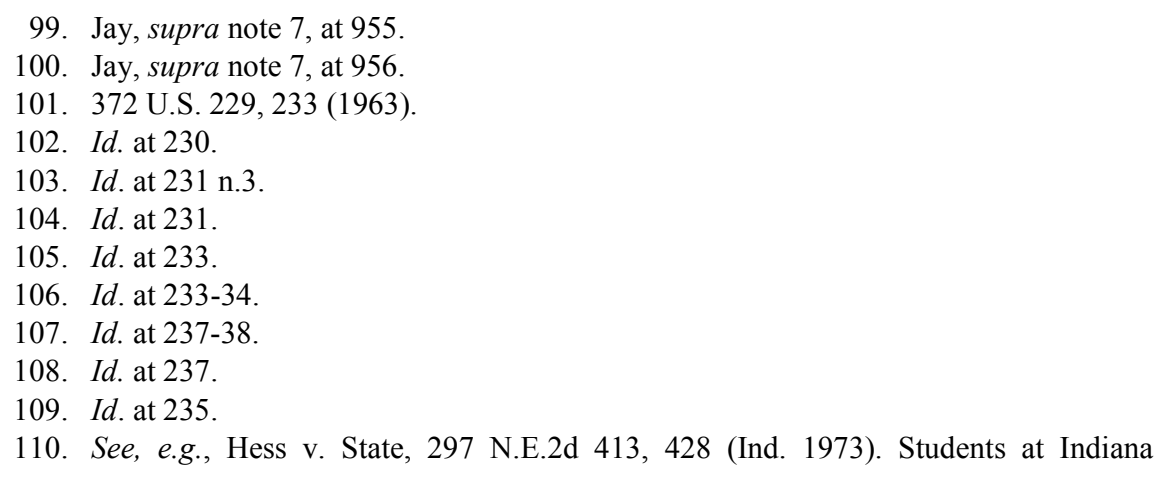


racial intricacies marked a defining moment for just how the First Amendment protects Americans. In NAACP v. Claiborne Hardware, the NAACP ran a boycott against white merchants, whom they thought were racist, as a means to instill racial justice. ${ }^{111}$ Individuals were placed near these stores to catch blacks that entered them, and in several instances the blacks were then ostracized and victimized by violence (by other blacks) during the first year of the boycott. ${ }^{12}$ The merchants sued, claiming an illegal conspiracy to harm their businesses, and won at trial. ${ }^{113}$ The Supreme Court reversed unanimously. ${ }^{114}$ It argued a difference between a boycott for economic purposes, as is a labor strike, and boycotting for political motivations. ${ }^{115}$ Justice Stevens, in the majority opinion, stated that "speech concerning public affairs is more than self-expression; it is the essence of self-government." 116 Despite instances of violence, the Court affirmed the protection of "a [mostly] nonviolent, politically motivated boycott designed to force governmental and economic change and to effectuate rights guaranteed by the Constitution itself." 117 Such questionable tactics, coercive in nature, were deemed legal: "speech does not lose its protected character, however, simply because it may embarrass others or coerce them into action." 118

At this juncture in US First Amendment history, the Supreme Court had nullified unwarranted paranoia against political affiliation, even in times of looming nuclear war. ${ }^{119}$ They had allowed public displays of protest against the social state of the country-despite police discretion. ${ }^{120}$ They had upheld free speech even in instances of possible economic stagnation caused by coercion, embarrassment, and ridicule. ${ }^{121}$ This is how the First Amendment established its prowess in US judicial history.

\footnotetext{
University were blocking the entrance of a school building to protest war. Id. Police started making arrests when one man shouted, "We'll take the fucking street later" or "We'll take the fucking street again." Id. He was arrested and charged a nominal fine of one dollar. Id. The court reversed the conviction because of lack of immediacy. Id.

111. 458 U.S. 886,887 (1982).

112. Id. at $887,903-04$.

113. Id. at 893 .

114. Id. at 934 .

115. Id. at 913 .

116. Id. (quoting Garrison v. Louisiana, 379 U.S. 64, 74-75 (1964)).

117. Id. at 914 .

118. Id. at 1002.

119. See generally Robel, 389 U.S. at 266-268.

120. Edwards v. South Carolina, 372 U.S. 229, 235 (1963).

121. See generally Claiborne, 458 U.S. 886.
} 


\section{THAI LÈSE-MAJESTÉ LAW TODAY}

\section{A. Recent Statistics and Constitutional Lèse-Majesté}

For purposes of this Note, Thai lèse-majesté law "today" refers roughly to the last twenty years, or from 1993 to the writing of this Note. Although human civilization has departed from monarchies towards democratic principles, Thai lèse-majesté law has shown an increased subversion of the people and an amplification of royal dominance and superiority: there has been an average of five cases per year between 1992 and 2004, with 231 lèse-majesté cases tried in 2006 and $2008 .{ }^{122}$ Reports indicate a whopping 3,000 cases were investigated in 2009 alone. ${ }^{123}$

This police power comes partly from the Thai Constitution, last revised in 2007, which establishes the supremacy of the monarchy: "The King shall be enthroned in a position of revered worship and shall not be violated. No person shall expose the King to any sort of accusation or action." 124 However, the document avers a democratic system with the people seemingly at the same level as the monarchy for purposes of the law: "Thailand adopts a democratic regime of government with the King as Head of State. . . . The sovereign power belongs to the Thai people." There is also a provision on free speech protections: "A person shall enjoy the liberty to express his opinion, make speech, write, print, publicize, and make expression by other means." ${ }^{\prime 26}$ Nonetheless, the royal exception, or rather, the "national security" exception of lèse-majesté and related provisions, quickly limit the freedoms of expression in the same section:

The restriction on liberty under paragraph one shall not be imposed except by virtue of the law specifically enacted for the purpose of maintaining the security of State, protecting the rights, liberties, dignity, reputation, family or privacy rights of other persons, maintaining public order or good morals or preventing or halting the deterioration of the

122. Connors, supra note 44 , at 662.

123. Connors, supra note 44, at 662.

124. Constitution of the Kingdom of Thailand, B.E. 2550 (2007), s. 8, archived at http://perma.cc/RK2P-3GQ7.

125. Id., s. 2-3. One commentator has concluded that this provision is more or less a joke, and that the Thai people have never been the sovereign despite this claim and others: "It is necessary to state the obvious: in Thailand 'the people' have never been sovereign. Any pretentions to the contrary have regularly ended when the tanks once again roll out onto the streets.” David Streckfuss, Truth on Trial in Thailand: Defamation, Treason, and LÈSE-MAJESTÉ 296 (2011).

126. Constitution of The Kingdom of Thailand, B.E. 2550 (2007), s. 45, archived at http://perma.cc/KAQ6-68XC. 
mind or health of the public. ${ }^{127}$

\section{B. Arresting Your Reflection—the Sawasdi Amornivat Case}

Lèse-majesté law's national security purpose would lend the outside observer, or even Thai residents, to presume that those employed by the State for national security and public safety purposes would enjoy some degree of special protection from the law - that may not be so. There is perhaps no case better than that of Police General Sawasdi Amornvivat to illustrate the reaches of absurdity and arbitrariness that lèse-majesté law (especially in a world with increasing media forms, including cross-national media) creates. ${ }^{128}$

In August of 1993, Amornvivat, serving as chief of Thailand's Police Department and Print Officer, banned an issue of the Honolulu Advertiser in which one article allegedly insulted the Queen. ${ }^{129}$ Naturally, the banning order was published, along with the insulting portions of the article, in the Royal Gazette of Thailand, the government's official periodical. ${ }^{130}$ Later, a lawyer asked the police to investigate the chief's actions because republishing the insulting portions in the Gazette was a lèse-majesté violation itself. $^{131}$ The lawyer alleged that the reporting of the original violation of lèse-majesté was "instrumental in spreading the story damaging to the Royal Family." 132 The king, trying to stop the nonsense, stepped in and pardoned the chief after the Interior Minister Chavalit Yongchaiyut dismissed the chief. ${ }^{133}$ The Minister, however, nullified the king's pardon since that could, as a matter of procedure, only be effective after a guilty finding. ${ }^{134}$

Later, another party, Police Lieutenant-General Supas Chiraphan, accused the Interior Minister of lèse-majesté because "to brush aside a royal pardon is an act of lese-majeste." 135 Then, another policeman accused the chief of leaking an article in the Daily Ex-press, a British periodical, that suggested the prince or princess could succeed the king (apparently, such

127. Id.

128. Streckfuss, supra note 1 , at 461.

129. Streckfuss, supra note 1 , at 461.

130. Streckfuss, supra note 1 , at 461 .

131. Streckfuss, supra note 1, at 461; see also Thai Facebookers Get a New Royal Warning, THAILAND Flooding 2011 (Nov. 26, 2011), http://hailandflooding.blogspot.com/2011/11/thai-facebookers-get-new-royal-warning.html, archived at http://perma.cc/7LQR-DWE2.

132. Streckfuss, supra note 1, at 461.

133. Streckfuss, supra note 1 , at 461.

134. Streckfuss, supra note 1 , at 461.

135. Streckfuss, supra note 1, at 461 (quoting Bangkok Post Weekly Review, November 5 and 12, December 10, 1993; Bangkok Post, October 21, 26, 27, and December 4 and 7, 1993; Nation, October 15, 1993). 
speculation was sufficiently insulting). ${ }^{136}$ At this point in the debacle, with the investigations of charges pending, Supas Chiraphan remarked tonguein-cheek, "will the investigators have to refer to the offending remarks in concluding their investigation report? If so, will this also be considered lese-majeste?" "137 In total, although the king again stepped in to deny any offense taken starting from the first incident, Sawasdi and five other officers were issued arrest warrants. ${ }^{138}$ As a sigh of relief regarding this whole incident, all charges were dismissed on a technicality: the Gazette was a "state publishing arm" and had "no publisher," and since only published insults could be disciplined, the parties involved were not liable. ${ }^{139}$

This case was an embarrassing string of finger-pointing, essentially mocking the very law designed to mitigate mockery or challenges to the monarchy especially because the king's impositions were essentially negated and ignored. Arguably, this case raised eyebrows as to who really benefits from such law: the royalty, or politicians and other State officials who keep civilian behavior - and their own - in check?

Indeed, academics such as Giles Ji Ungphakorn have challenged the law, presuming political rather than monarchical supremacy as the force of the law. ${ }^{140}$ At the Eight International Thai Studies Conference of 2002 in the city of Nakhon Phanom, he expressed a preference for a republic rather than the status quo pseudo monarchical-democratic system. ${ }^{141}$ Though heard by 300 people in what was arguably a violation of the easily provoked law, no action was taken against Ungphakorn. ${ }^{142}$ Nevertheless, as he became a more popular activist and member of the red-shirt movement in 2008, he was charged with lèse-majesté for his book "A Coup for the Rich." "Ungphakorn is now in exile and therefore not constrained by the

136. Streckfuss, supra note 1 , at 461.

137. Streckfuss, supra note 1, at 461 (quoting Bangkok Post Weekly Review, November 5 and 12, December 10, 1993; Bangkok Post, October 21, 26, 27, and December 4 and 7, 1993; Nation, October 15, 1993).

138. Streckfuss, supra note 1, at 461-62.

139. Streckfuss, supra note 1 , at 462.

140. Connors, supra note 44, at 660.

141. Connors, supra note 44 , at 660 .

142. Connors, supra note 44 , at 660 .

143. Connors, supra note 44, at 660; see also A Coup for the Rich: Thailand's Political Crisis, 2007, WIKILEAKS (Jan. 19, 2009), http://wikileaks.org/wiki/A_Coup_for_the_Rich:_Thailand's_Political_Crisis,_2007, archived at http://perma.cc/US4U-9BNW ("The book criticizes the 2006 military coup and the liberals who supported the coup. It discusses the role of the Thai Monarchy, citing the work of Paul Handley, The King Never Smiles. There is a chapter on the politics of the People's Movement. The final chapter deals with the crisis in the South of the Thailand."). Evidently, affiliation with the "other side" of the political spectrum-being part of the "yellow-shirt" movement-is no safeguard to lèse-majesté law: in October 2013, Sondhi Limthongkul, a founder of the royalist "yellow-shirt" movement was sentenced to two years "for quoting remarks made by an anti-establishment activist to a crowd at a protest in 2008." 
relentless forbiddance of political criticism in his native Thailand. ${ }^{144}$ His main academic position regarding such issues is that the military is the real power behind the throne. ${ }^{145}$ Perhaps Ungphakorn is best described as a living example of how academic criticism, if outside the mainstream, can dodge criminal prosecution, at least temporarily.

\section{Uncle SMS and Lèse-Majesté in Technology}

More recently, Thai lèse-majesté law has kept pace with the innovative ways by which citizens worldwide have expressed concern and opposition to despotic or near-despotic rule. ${ }^{146}$ Despite hopes of the repeal of an outdated and suppressive law, the current military junta has and the previous government of Prime Minister Yingluck Shinawatra had kept Thai lèse-majesté law on the books. ${ }^{147}$ Inspired by the sea of technologically supported uprisings in Tunisia and Egypt, human rights defenders, activists, and journalists in Thailand have used technology and more traditional means of protest to voice concerns of lèse-majesté law. ${ }^{148}$ These protests include everything from internet postings to text messages.

A sixty-one year-old man, Ampon Tangnoppakul, allegedly sent four text messages to a government official about the Thai monarchy. ${ }^{149}$ The illadvised texts were deemed offensive and the elder was sentenced to twenty years in prison. Dubbed "Uncle SMS," Tangnoppakul "denied all charges, claiming that he did not even know how to send a text message." ${ }^{150}$ Sadly, he died soon after his conviction in a Bangkok prison hospital. ${ }^{151}$ His death

Thanyarat Doksone, Thai Royalist Sentenced for Repeating Royal Insult, YAHOO! NEwS (Oct. 2, 2013, 1:04 AM), http://news.yahoo.com/thai-royalist-sentenced-repeating-royalinsult-050405844.html, archived at http://perma.cc/5QRT-4SMU. Sondhi intended to help prosecute the activist and protect the establishment's honor; however, like in the Amornvivat case, Sondhi was a victim of the boomeranging effect of Thailand's oft pragmatically absurd lèse-majesté law. See id.

144. Connors, supra note 44 , at 660.

145. Connors, supra note 44, at 660. More recently, Ungphakorn's foreshadowing was perhaps vindicated as the Thai military took control of the government and now rules by a military junta. Catherine E. Shoichet, Thailand Coup: A Cheat Sheet to Get You Up to Speed, CNN (May 23, 2014), http://www.cnn.com/2014/05/21/world/asia/thailand-crisis-upto-speed/, archived at http://perma.cc/LEL7-MUUG. Recent political changes began with mass organized rallies against the former Yingluck Shinawatra government. Id. Eventually, because of the ongoing protests, the military executed a coup d'état which then established the junta. $I d$.

146. See Amnesty Int'L, Amnesty International Report 2012: The State of the WORLD'S HUMAN RIGHTS 22-23 (2012).

147. Id.

148. Id. at 22 .

149. An Inconvenient Death: A Sad Story of Bad Law, Absurd Sentences and Political Expediency, ECONOMIST (May 12, 2012), http://www.economist.com/node/21554585, archived at http://perma.cc/K3RK-HMYM.

150. Id.

151. Id. 
made national news and likely provoked shock and disappointment among many. ${ }^{152}$ One reason behind the shock was that the aforementioned Prime Minister partly gained power because of "red shirt" activists who supported her brother, former Prime Minister Thaksin Shinawatra who was exiled for lèse-majesté violations, and therefore supported her as a matter of loyalty. ${ }^{153}$

\section{The King's Speech}

These internal political contradictions regarding lèse-majesté law were culminated by the words of the current king, His Majesty King Bhumibol Adulyadej, during his official birthday speech in 2005. Following up Thaksin Shinawatra, and holding the attention of much of the whole country, he made shocking remarks that implicated enforcement of lèsemajesté law and the freedom of the Thai people to criticize the monarchy. Here is a portion of the speech:

It is normal that everyone likes compliments and does not like to be criticised. . . . People who are in the open are normally seen more and are criticised more because of more public exposure. . . . If people feel that they are criticised and show that they are upset for being criticised, there will be damage and there will be turmoil in society. .

[T] here are people who said that I am not good, the King is not good and did wrong, but . . . under the Constitutional Monarchy . . . the King can do no wrong. . . .

$[\mathrm{T}]$ here are textbooks that always claim ... . how the King can do no wrong. . . . [But] that the King can do no wrong is very much an insult to the King, . . . because this shows that they regard that the King is not human. But the King can do wrong. ${ }^{154}$

152. Id.

153. Id.; see also STRECKFUSS, supra note 125, at 3 ("The coup, which overthrew the democratically-elected government of then prime minister, Thaksin Shinawatra, helped solidify two opposing groups - the 'yellow shirts' (the People's Alliance for Democracy, or PAD, supporters of the monarchy, the military, and a limited democracy) and the red-shirts (anti-coup, pro-the United Front for Democracy against Dictatorship, or UDD, mostly Thaksin supporters). The backdrop to recent political events in Thailand-the protests against Thaksin in early 2006, the coup in September of that year, and the division in Thai society made so strikingly evident as society squared off into yellow and red-was the monarchy and the curious lèse-majesté law protecting it.").

154. His Majesty King Bhumibol Adulyadej of Thailand, The King's 78th Birthday Address (Dec. 4, 2005) (emphasis added), archived at http://perma.cc/D2QJ-5N6B 
What is irreconcilable about this speech, which went on about the need for criticizing the monarchy, ${ }^{155}$ is that lèse-majesté charges steadily continued after it, and do not seem to be slowing down anytime soon. ${ }^{156}$ It remains to be seen what will happen when King Bhumibol is succeeded, and how the new ruler will stand on the issue of criticism of the monarchy.

Between a case showing the potential absurdity of Thai lèse-majesté law, ${ }^{157}$ continuing difficulties of academics to properly analyze and assess the implications of the law, ${ }^{158}$ and a call to encourage criticism of the king made by the king himself, ${ }^{159}$ Thailand has seen interesting developments of its free speech laws in the last twenty years. Unfortunately, the biggest problem, that such a draconian law is still at play and long incarcerating people for expressing opinion, is still intact.

\section{US FIRST AMENDMENT FREEDOMS TODAY}

\section{A. Express as You Please_Village of Skokie and Texas v. Johnson}

The end of the civil rights era and the inertial cases thereafter opened a new chapter for the judicial and societal development and understanding of First Amendment freedoms. It marked, for some, a striking embrace of easily offensive and sometimes dark viewpoints to the great emotional burden of American communities. ${ }^{160}$ Adopters of these viewpoints were granted their liberty, however, riding the notion that the First Amendment allows expression regardless of its offensive nature. ${ }^{161}$ This chapter saw the vindication of a torched American flag ${ }^{162}$ and the Supreme Court's first decree of internet openness. ${ }^{163}$ The last decade or so has been particularly fruitful for First Amendment developments because of a game-changing political campaign contribution decision, ${ }^{164}$ anti-income-inequality uprisings, ${ }^{165}$ and the bold practices of a church that is arguably dancing on the fine line between earnest expression of matters of public concern and

[hereinafter Birthday Speech].

155. Id.

156. Pitman \& Tunsarawuth, supra note 4; see also STRECKFUSS, supra note 125 , at 6 (noting that there have been "court actions on 765 cases between 2006 and 2009-an average of almost 191 per year - an increase over the immediate previous decade when there was of an average of just five new cases per year").

157. Streckfuss, supra note 1, at 461-62.

158. See Connors, supra note 44 and accompanying text.

159. Birthday Speech, supra note 154.

160. See generally infra notes 167-174, 212-235 and Part V.D.

161. See Texas v. Johnson, 491 U.S. 397, 414 (1989) ("If there is a bedrock principle underlying the First Amendment, it is that the government may not prohibit the expression of an idea simply because society finds the idea itself offensive or disagreeable.").

162. See infra notes $175-80$ and accompanying text.

163. See infra notes 191-94 and accompanying text.

164. See infra Part V.C.

165. See infra notes $181-90$ and accompanying text. 
abuse of free speech. ${ }^{166}$

Earnest expression in the United States can take forms exalting some of the most tragic events in human history. In Village of Skokie v. National Socialist Party of America, a group advocating for the philosophies of the German Nazi Party, the National Socialist Party of America, was sued for planning a march through the village of Skokie, Illinois. ${ }^{167}$ There, 40,500 of 70,000 inhabitants were of Jewish religion or ancestry, of which 5,000 to 7,000 were survivors of Nazi concentration camps. ${ }^{168}$ The Skokie Park District required $\$ 350,000$ as a liability deposit for the Party's use of village parks, so the Party gave notice of a demonstration through the village to protest the insurance requirements. ${ }^{169}$ The village moved to enjoin the demonstration arguing that Nazi symbols, particularly the swastika, would provoke a violent reaction by villagers. ${ }^{170}$ The Supreme Court did sympathize with the villagers: "We do not doubt that the sight of this symbol is abhorrent to the Jewish citizens of Skokie, and that the survivors of the Nazi persecutions, tormented by their recollections, may have strong feelings regarding its display." ${ }^{171}$ Nevertheless, they held that displaying the swastika was a symbolic form of free speech entitled to First Amendment protections. ${ }^{172}$ It was insufficient that the display may provoke a violent reaction for otherwise peaceful demonstrations to be denied. ${ }^{173}$

Skokie spoke volumes to how far American legal system will go to maintain the inalienable right to express a viewpoint. There is always a difference of opinions to public matters. The Court here only clarified that the degree of opposition to opinions, no matter how deep the cut, is negligible vis a vis the freedom to stand on personal or group convictions. ${ }^{174}$

Convictions need not be projected through voice alone. Often, expression takes the form of physical action-like destruction. During the Republican National Convention in Dallas in 1984, demonstrators protested the policies of the Reagan administration and certain corporations. ${ }^{175}$ One impassioned demonstrator culminated the backlash by burning the American flag. ${ }^{176} \mathrm{He}$ was charged under a Texas statute for desecrating a venerated object. ${ }^{177}$

The question before the Supreme Court was whether the burning was

166. See infra Part V.C.

167. 373 N.E.2d 21, 22 (Ill. 1978).

168. $I d$.

169. Id.

170. Id.

171. Id. at 24 .

172. Id. at 25 .

173. Id.

174. Id. at 24 .

175. Texas v. Johnson, 491 U.S. 397, 399 (1989).

176. Id.

177. Id. at 400 . 
an "expression" protected by the First Amendment. "We have not automatically concluded, however, that any action taken with respect to our flag is expressive. Instead, in characterizing such action for First Amendment purposes, we have considered the context in which it occurred." ${ }^{178}$ His conduct was found "overtly political . . . both intentional and overwhelmingly apparent." 179 The flag burning had to pass a test that it was a communication, and that it was meaningful and symbolic, rather than a crude defacing of a national symbol. ${ }^{180}$ Ironically, the same flag burned by defendant represented a nation that allows such revolt. But how far can revolt go, and can it be done conveniently without interference in public places? Does the Constitution compel the government to minimize resistance during protest, or to offer concessions to make the process easier?

\section{B. Tents and the Internet-Occupy Wall Street and Reno v. ACLU}

The Occupy Wall Street movement, a creature of the economic recession and continuing income gap in the United States, has helped answer these questions. What started in Zucotti Park in New York City caught on like wild fire and spread throughout the United States, bringing scores of protestors to public gathering points, demanding reforms to strengthen income equality in the several states. ${ }^{181}$ This text marked the start of the uprisings: "WHAT IS OUR DEMAND? \#OCCUPYWALLSTREET SEPTEMBER $17^{\mathrm{TH}}$ - BRING TENT." "182 The call to bring tents was all too serious, for as one commentator noted, "to occupy these spaces was to transform them."

The protests themselves were protected by the First Amendment. ${ }^{184}$ Their concept is perhaps the paradigmatic embrace of the constitutional right to free speech. Nevertheless, there has been litigation concerning the ambitious, twenty-four-hours-a-day stationing of protestors in public spaces. In Occupy Fort Myers v. City of Fort Myers, the district court held that elongated stays of protest were symbolic representations with First Amendment protection. ${ }^{185}$ However, reasoned restrictions were allowed: "symbolic expression 'may be forbidden or regulated if the conduct itself may constitutionally be regulated, if the regulation is narrowly drawn to further a substantial governmental interest, and if the interest is unrelated to

\footnotetext{
178. Id. at 405 .

179. Id. at 406 .

180. Id.

181. Sarah Kuntsler, The Right to Occupy-Occupy Wall Street and the First Amendment, 39 Fordham URB. L.J. 989, 989 (2010).

182. Id. at 990 .

183. Id. at 992 .

184. Id. at 1012 .

185. 882 F. Supp. 2d 1320, 1328 (M.D. Fla. 2011).
} 
the suppression of free speech." "186 Thus, a city ordinance prohibiting use of tents and other structures for overnight camping was upheld. ${ }^{187}$

Other courts followed suit. In Occupy Minneapolis v. County of Hennepin, the court allowed the plaintiff's First Amendment challenges against banning erected structures during Occupy protests in Minnesota. ${ }^{188}$ However, invoking Clark v. Community for Creative Non-Violence, the court decided that a resolution banning sleeping and erecting tents and other structures on a plaza next to the government center was a valid time, place, and manner restriction. ${ }^{189}$ The Occupy movement and the cases following it prove the First Amendment is not boundless. Where one freedom hinders the exercise of potentially many others, judicial pragmatism puts the foot down. ${ }^{190}$

Beyond political or cultural protest, First Amendment freedoms allow access to information, freeing up the universe of ideas on the internet. In Reno v. American Civil Liberties Union, the plaintiff challenged the constitutionality of the Communications Decency Act which limited "indecent" and "patently offensive" (e.g., pornographic) material on the internet where it could readily be accessed by people under eighteen years old via easily circumvented age verification. ${ }^{191}$ This was the first Supreme Court decision involving cyberspace, and therefore incredibly influential for the myriad of internet cases to come before the tribunal. ${ }^{192}$

The Court affirmed the district court's decision that the limitations placed an unacceptably heavy burden on protected free speech. ${ }^{193}$ The decision was based not on the interest of children's free speech, but on adults whose online interactions would be limited, especially with other adults, if such a broad, blanketed restriction were upheld to protect children. Reno represented the First Amendment's ability to adapt to an evolving human society. Indeed, because so many people today speak and express through the web, it is axiomatic that the First Amendment apply to the internet. $^{194}$

186. Id. at 1330 (quoting Clark v. Community for Creative Non-Violence, 468 U.S. 288, 294 (1984)).

187. Id. at 1337.

188. 866 F. Supp. 2d 1062, 1069 (2011).

189. Id. at 1071; see generally Clark 468 U.S. 288 (1984).

190. See id. Likewise, in Occupy Columbia v. Haley, the court found that "the Plaintiffs are likely to establish that Occupy Columbia's camping on the State House grounds is expressive conduct, as defined by Spence," but upheld an "emergency regulation" banning camping and sleeping. 866 F. Supp. 2d 545, 557, 563 (2011).

191. 521 U.S. 844, 849 (1997).

192. Reno v. ACLU (1997), INFO PLEASE, http://www.infoplease.com/us/supremecourt/cases/ar33.html (last visited Jan. 13, 2013, archived at http://perma.cc/QR3J-2RB4).

193. Reno, 521 U.S. at 882.

194. Id. at 876 . 


\section{Citizens United}

Today, the internet is the new kid on the "development of judicially interpreted free speech" block, but television, particularly on-demand television, has made big noise in the second decade of the new millennium. In the landmark and thickly controversial Citizens United v. Federal Election Commission, Citizens United, a non-profit corporation, brought an action to a District of Columbia District Court. ${ }^{195}$ Citizens produced and wanted to air a documentary negatively depicting US Senator Hillary Clinton. Citizens was prepared to pay for a slot on video-on-demand to implement the proposal. ${ }^{196}$ "It produced two 10-second ads and one 30second ad for 'Hillary.' Each ad included a short [] statement about Senator Clinton, followed by the name of the movie and the movie's Website address." 197

Federal law prohibited "corporations and unions from using general treasury funds to make direct contributions to candidates or independent expenditures that expressly advocate the election or defeat of a candidate, through any form of media, in connection with certain qualified federal elections." 198 The Bipartisan Campaign Reform Act of 2002 was the statutory equivalent of this law. ${ }^{199}$

Citizens took a proactive approach to the risk of legal sanctions by suing the FEC, seeking declaratory and injunctive relief claiming that airing the video with company funds was constitutionally protected. ${ }^{200}$ The FEC's main argument was that government cannot favor particular speech or speakers over others by not promoting the others. ${ }^{201}$ It cannot take sides, and doing so puts the disfavored speakers at a disadvantage. ${ }^{202}$ However, the cases cited for this argument were in the context of free speech restrictions upheld for the proper functioning of governmental entities. ${ }^{203}$

195. 130 S. Ct. $876,886-87$ (2010).

196. Id. at 887 .

197. Id (alteration added).

198. Id. (citing 2 U.S.C $§ 441 b$ (2000 ed.))

199. See id.

200. Id. at 888 .

201. Id. at 898-99.

202. Id. This argument is strengthened because the checks and balances of the US governmental system and Constitution try to protect the voice of the minority (as well as the majority) through neutrality in regards to political advocacy. See Christopher Gardner, Constitutional Balance of Powers Helps Avoid Tyranny of Majority (and Minority), MKCREATIVE (July 7, 2010), http://www.mkcreative.net/blog/2010/07/07/constitutionalbalance-of-powers-helps-avoid-tyrrany-of-majority-and-minority, archived at http://perma.cc/RCE4-2Y2L.

203. Citizens, 130 S. Ct. at 899; see, e.g., Bethel School Dist. No. 403 v. Fraser, 478 U.S. 675 (1986) (protected public school education); Jones v. North Carolina Prisoners' Labor Union, Inc., 433 U.S. 119 (1977) (promoted penological application in the corrections system); Parker v. Levy, 417 U.S. 733 (1974) (ensured the capacity of the US government to 
Therefore, the Court was not persuaded. ${ }^{204}$ It stated the First Amendment's most urgent application is for political campaign speech. ${ }^{205}$ "Political speech does not lose First Amendment protection "simply because its source is a corporation." "206 The holding was simple in scope: no government interest for suppressing political speech of nonprofit and forprofit corporations meets the strict scrutiny standard. ${ }^{207}$

Criticism of Citizens came from unexpected places. Conservative Judge Richard Posner told an assembly of foreign educators that unabashed legislators promote the interests of wealthy donors to maintain the stream of cash. ${ }^{208}$ He posited that "our political system is pervasively corrupt due to our Supreme Court taking away campaign-contribution restrictions on the basis of the First Amendment."209

Perhaps less unexpectedly, but equally vigilant were the remarks of John McCain, a Republican senator from Arizona, who called the ruling the Supreme Court's "worst decision ever." ${ }^{210} \mathrm{He}$ was appalled that the bench (according to him) equated money to free speech. ${ }^{211}$ Indeed, this decision marked a change in the US political landscape. Gaining elected political office, especially in higher positions of power, now necessitates considerably competitive campaign funding - at least much higher than before. $^{212}$ Because historically it takes wealth, power, or status to start a competitive political campaign for some offices, Citizens United topples the playing field for fair access in effecting political change, a foundational principle of the First Amendment, by using the First Amendment itself.

discharge its military responsibilities); Civil Service Comm'n v. Letter Carriers, 413 U.S. 548 (1973) (contemplated evaluation of federal military service).

204. Citizens, 130 S. Ct. at 899.

205. Id. at 898 .

206. Id. at 900 (quoting First Nat'l Bank of Boston v. Bellotti, 435 U.S. 765, 784 (1978)).

207. Id. at 913 . To meet the strict scrutiny standard, a law or policy must 1) serve a compelling government interest and 2) be narrowly tailored to advance that interest. Elizabeth S. Anderson, Integration, Affirmative Action and Strict Scrutiny, 77 N.Y.U. L. REV. 1195, 1228 (2002). For a thorough analysis of strict scrutiny in US federal courts, see Adam Winkler, Fatal in Theory and Strict in Fact: an Empirical Analysis of Strict Scrutiny in the Federal Courts, 59 VAND. L. ReV. 793 (2006).

208. James Warren, Richard Posner Bashes Supreme Court's Citizens United Ruling, DAILY BEAST (July 14, 2012), http://www.thedailybeast.com/articles/2012/07/14/richardposner-bashes-supreme-court-s-citizens-united-ruling.html, archived at http://perma.cc/ACR8-NTXU.

209. Id.

210. Nick Wing, John McCain: Citizens United is 'Worst Decision Ever' . . 'Money is Money,' Not Free Speech, HuFFIngTon Post, http://www.huffingtonpost.com/2012/10/12/john-mccain-citizens-united_n_1960996.html (last updated Oct. 13, 2012, archived at http://perma.cc/9DCF-HH3S).

211. Id.

212. The Power of Money: The Ethics of Campaign Finance Reform, 3 IssuES IN ETHICS (1990), archived at $\mathrm{http}: / /$ perma.cc/K8S8-TLMG. The average congressional campaign costs $\$ 1$ million, and the average senate campaign costs $\$ 4.3$ million. Id. 


\section{Westboro Baptist Church}

Some efforts at effecting political and social change are bolder than others. The Snyder v. Phelps decision concerning the Westboro Baptist Church is proof. The case was on appeal from a jury that held the church's members liable for millions of dollars for picketing near the funeral service of Marine Lance Corporal Matthew Snyder. ${ }^{213}$ Westboro's signs used provocative language to express the church's stance against tolerance of homosexuality in America. The church's stances included that deaths of soldiers and other tragedies like 9/11 were god's way of punishing the nation's increasing acceptance of same-sex relationships and sexual activity. ${ }^{214}$ The signs read: "'God Hates the USA/Thank God for 9/11,' 'America is Doomed,' 'Thank God for Dead Soldiers,' 'Priests Rape Boys,' 'God Hates Fags,' and 'God Hates You,'” among other messages. ${ }^{215}$ The Snyders sued for intentional infliction of emotional distress. ${ }^{216}$

The Court reasoned that "the First Amendment reflects 'a profound national commitment to the principle that debate on public issues should be uninhibited, robust, and wide-open." ${ }^{217}$ The bench emphasized the grave consequences of quieting speech that reflected matters of public interest: less free and robust debate on public issues, mitigating the meaningful dialogue of ideas, and self-censorship in discussing public matters. ${ }^{218}$ The prosecution's main argument was that such ugly methods of expression were empty, twisting earnest dialogue about serious public issues through ridicule and unabated attention-seeking for religious interests. ${ }^{219}$ The court disagreed. $^{220}$ "While these messages may fall short of refined social or political commentary, the issues they highlight - the political and moral conduct of the United States and its citizens, the fate of our Nation, homosexuality in the military, and scandals involving the Catholic clergyare matters of public import." ${ }^{221}$ Thus, the Court created precedent that no manner of expression is too crude or deemed a publicity stunt in the eyes of the law, if it fits "public import" and other parameters - even if it inflames emotional distress in citizens. ${ }^{222}$

Justice Alito's dissent was remarkable, but perhaps only because it outlined the antithesis of the majority's interpretations of Westboro's

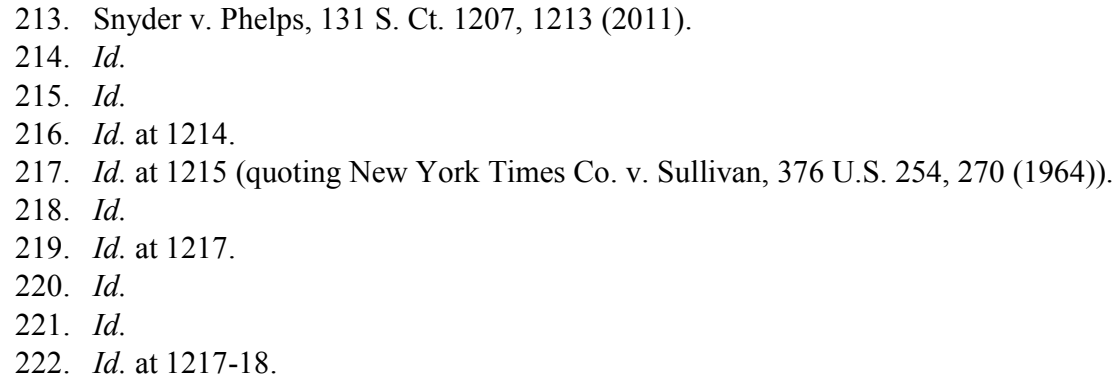


methods. His analysis centered on the idea that the substance of Westboro's expressions did not contribute to a meaningful discussion on, inter alia, homosexuality. ${ }^{223}$ "The First Amendment does not shield utterances that form 'no essential part of any exposition of ideas, and are of such slight social value as a step to truth that any benefit that may be derived from them is clearly outweighed by the social interest in order and morality.",224 He dubbed Westboro's methods "strategy" for garnering attention through provocation. ${ }^{225}$ If, in fact, that is the driving force behind Westboro's acts, then Alito's judgment is the right one; however, there has been no evidence that Westboro is not earnest in its ways such as to recant the benefit of the doubt given to them by the Supreme Court. 226

Snyder was ripe with controversy like Citizens. ${ }^{227}$ What is more, opponents of this decision have made unlawful threats to the church. Hacktivist $^{228}$ group Anonymous apparently hacked Westboro's website in response to its expression methods. ${ }^{22}$ The apparent vigilante conduct included posting church members' names, phone numbers, e-mail addresses, and physical addresses online for public viewing. ${ }^{230}$ To speculate, this may have been done to physically threaten and perhaps abuse church members.

Government action against Westboro has been urged by more than 300,000 Americans through the White House's online petition system. ${ }^{231}$ This petition is the most popular since the website's inception and was started after Westboro vowed to picket the funerals of the Sandy Hook massacre victims. ${ }^{232}$ It demanded the White House recognize Westboro as a hate group - something the government has not done to any organization. ${ }^{233}$

223. Id. at 1222 .

224. Id. at 1223 (quoting Chaplinsky v. New Hampshire, 315 U.S. 568, 572 (1942)).

225. Id.

226. Id. at 1211.

227. Warren, supra note 208.

228. See Peter Ludlow, What is a 'Hacktivist'?, N.Y. TiMEs (Jan. 13, 2013, 8:30 PM), http://opinionator.blogs.nytimes.com/2013/01/13/what-is-a-hacktivist/, archived at http://perma.cc/ZBS9-3R3Z.

229. Steven Musil, Hackers Target Westboro Baptist Church after Newtown Threat, CNET, http://news.cnet.com/8301-1023_3-57559468-93/hackers-target-westboro-baptistchurch-after-newtown-threat/ (last visited Jan. 4, 2013, archived at http://perma.cc/RD3J$33 \mathrm{AW})$.

230. Id.

231. Kristen A. Lee, Petition to Label Westboro Baptist Church a 'Hate Group' is Most Popular on White House Website, N.Y. DAILY NEWS (DEC. 27, 2012, 10:40 AM), http://www.nydailynews.com/news/politics/265k-sign-petition-label-westboro-hate-grouparticle-1.1228100.

232. Id.

233. Mike Hendricks, Anti-Westboro Petition Has Most Signatures on White House Website, KANSAS CITY STAR (Dec. 28, 2012), http://www.kansascity.com/2012/12/27/3983779/anti-westboro-petition-sets-new.html, 
Because such action would be novel, it is uncertain what it would accomplish. ${ }^{234}$ Commentators have suggested that Westboro may lose its status as a tax-exempt organization. ${ }^{235}$ The government has yet to give an official response; ${ }^{236}$ however, because of the constitutional ruling in Phelps, such a request will likely be denied.

From Skokie to Phelps, the last thirty years or so of developments in US First Amendment freedoms have seen some major qualifications to broaden the scope of speech, and less so, to narrow it. One reason so many otherwise offensive and sometimes questionable forms of speech retain protection is to disallow a slippery slope weakening what are likely the strongest free speech protections worldwide. Through First Amendment jurisprudence, America has retained and advanced its position as the nation most valuing free speech liberties.

\section{RECOMMENDATIONS: HOW EMBRACING US FIRST AMENDMENT VALUES AND LEGAL PRACTICALITY CAN MOVE THAILAND FORWARD}

\section{A. A Call for the Repeal of Thai Lèse-Majesté Laws}

Thai lèse-majesté law is out of place. Technological advancements are multiplying the channels in which people can express their opinions. ${ }^{237}$ Political upheaval by civilians in the Middle East and Africa is driving out despots under the title of the Arab Spring. ${ }^{238}$ Now is not the time for censorship of the masses. Thai lèse-majesté law should be repealed.

One would think that the current king's invitation for criticism hinted that now is the time for repeal. ${ }^{239}$ It is absurd, moreover, that previous

archived at $\mathrm{http}: / /$ perma.cc/73U8-JMNN.

234. See generally id.

235. Kiri Blakeley, Petition Against Westboro Baptist Church May Finally Be Its Downfall, STIR (Dec. 26, 2012, $\quad 1: 21 \quad$ PM), http://thestir.cafemom.com/in_the_news/148675/petition_against_westboro_baptist_church, archived at $\mathrm{http}: / /$ perma.cc/UV8G-NWAB.

236. Hendricks, supra note 233.

237. Jack M. Balkin, Digital Speech and Democratic Culture: A Theory of Freedom of Expression for the Information Society, 79 N.Y.U. L. REV. 1, 36-37 (2004) (arguing not only that technological advancements provide more methods of expression, but that they should change our understanding of the social role of expression altogether).

238. See generally The Arab Spring: A Year of Revolution, NPR (Dec. 17, 2011, 6:02 PM), http://www.npr.org/2011/12/17/143897126/the-arab-spring-a-year-of-revolution, archived at http://perma.cc/8CLY-Y9EY; see also Tunisia Marks Arab Spring Revolution, AL JAZEERA, http://www.aljazeera.com/news/africa/2013/01/2013114767673554.html (last modified Jan. 14, 2013, archived at http://perma.cc/RY77-A3UU) (noting that Tunisians celebrated the second anniversary of their former leader's exile, and that Tunisia's uprising was the first of the Arab Spring uprisings).

239. Birthday Speech, supra note 154; Michael Aquino, Thailand's Strict "LèseMajesté" Laws - The Thai Reverence for the King, Aвоuт.com, http://goseasia.about.com/od/thaipeopleculture/a/lesemajeste.htm (last visited Nov. 18, 2012, 
Prime Minister, Yingluck Shinawatra, had, by maintaining the force of lèsemajesté, suffocated the ideology of the very people that were instrumental in her gaining the seat. ${ }^{240}$ Perhaps, as one scholar claimed, the law is less a watch on national security or symbolic protection of the monarchy than an instrument of military control ${ }^{241}$ - maybe another reason to be rid of it. Cross-analyzing US free speech decisions with Thai lèse-majesté decisions brings to light some of the holes in the Thai law's rationale.

The "disturbance of the peace" statutes in Edwards were supposed to prevent violence in the community. ${ }^{242}$ The rallying of the church members, although public, amplified, and perhaps notorious for the surrounding community, did not fit the narrow scope that would "permit [the] State to make criminal the peaceful expression of unpopular views."243

The Mungjaroen case was similar to Edwards because it involved a public gathering with the expression of unpopular views, but it was different because the Thai government thought one man's controversial views of the monarchy were enough to constitute a threat to national security. ${ }^{244}$ This Note argues that individual expressions, especially those simply giving a different account of history (here, that the king killed his brother to gain succession of the throne), ${ }^{245}$ are not reasonably sufficient to constitute speech which makes the king a subject of hate to the extent of a valid threat to national security. Even if there were a concern that it could start an uprising which in the aggregate could be a high-level threat, persistent advocates of such speech should be prosecution instead of those making ineffectual, unfounded reconstructions of monarchical history.

Another parallel can be drawn between political speech in Musikaphong and the boycott in the Claiborne Hardware case. ${ }^{246} \mathrm{Mr}$. Musikaphong's words were merely rhetorical in an arena where rhetoric is essential: political rallying. ${ }^{247}$ Moreover, the words were not aimed to bring hate to the royalty, but were used to absolve Musikaphong's colleague of accusations that she came from wealth and therefore would not make a

\footnotetext{
archived at http://perma.cc/AG9U-72BY).

240. See supra note 153 and accompanying text.

241. Connors, supra note 44; see also Otto F. von Feigenblatt, The Thai Ethnocracy Unravels: A Critical Cultural Analysis of Thailand's Socio-Political Unrest, 1 J. Alt. PersP. Soc. SCI. 583, 584 (2009), archived at http://perma.cc/JFW7-H4B6 ("Thailand, then known as Siam, remained deeply in the control of Bangkok elites, especially the military forces and the bureaucracy. This intervention by the military was the beginning of the continuing influence of the military in Thai politics.").

242. Edwards v. South Carolina, 372 U.S. 229, 234 (1963).

243. Id. at 237.

244. Streckfuss, supra note 1 , at 454.

245. Streckfuss, supra note 1 , at 454.

246. NAACP v. Claiborne Hardware, 458 U.S. 886, 887 (1982).

247. John Kane \& Haig Patapan, The Artless Art: Leadership and the Limits of Democratic Rhetoric, 45 AustL. J. PoL. SCI. 371, 372 (2010).
} 
suitable political candidate. ${ }^{248}$ In Claiborne Hardware, the circumstances were much more severe. ${ }^{249}$ There, an economic boycott staged to send a strong political message effected violence even within members of the black community. ${ }^{250}$ This was a bigger threat to peace, civility, and stable government than the Musikaphong situation; however, the Supreme Court made clear that the essence of self-government was self-expression. ${ }^{251}$ As to Thailand, its own constitution harks that the sovereign power belongs to the Thai people. ${ }^{252}$ Moreover, the apparent threat to the monarchy in the Musikaphong decision was dissected out of context, ${ }^{253}$ and speech during political campaigning should not be so harshly deemed to threaten national security when the purpose of speech during an effort to gain the people's votes is to effectuate governmental change. ${ }^{254}$

Arguably, monarchies are distinguishable from governments in a democratic system because their ideal form seems to resist change, ${ }^{255}$ whereas a democratic political structure welcomes change based on changing national principles, values, and attitudes. ${ }^{256}$ Indeed, Thailand and the United States have fundamental legal, social, and cultural differences. The United States is rooted in individualism ${ }^{257}$ and personal liberty. ${ }^{258}$ The US geo-political structure in which each state operates under its own

248. Streckfuss, supra note 1 , at 459.

249. Claiborne, 458 U.S. at 903-04.

250. Id. at 887 .

251. Id. at 913 .

252. Constitution of the Kingdom of Thailand, B.E. 2550 (2007), s. 3, archived at http://perma.cc/ZG7U-RATB.

253. Struckfuss, supra note 1, at 449-60.

254. Thailand has voted in favor of the Universal Declaration of Human Rights, which has several provisions asserting freedom of political speech that necessarily advocates change and differing opinion. Universal Declaration of Human Rights, G.A. Res. 217 (III) A, U.N. Doc A/Res/217(III), arts. 18-21 (Dec. 10, 1948). The US Supreme Court has asserted that such speech, dubbed "core political speech," is "interactive communication concerning political change." Meyer v. Grant, 486 U.S. 414, 422 (1988).

255. Andrzej Olechnowicz, The Monarchy and the British Nation: 1780 to the PRESENT 38 (Andrzej Olechnowicz ed., 2007) (noting generally how and why monarchs resist change); Mancur Olson, Power And Prosperity: Outgrowing Communist and CAPITALIST DictATORSHiPS 27, 28 (2000) (discussing the importance of succession as a measure of stability and maintenance of the status quo in monarchies and autocracies in particular).

256. Democracy Education for Iraq - Nine Brief Themes, STANFord UnIV., http://www.stanford.edu/ ldiamond/iraq/DemocracyEducation0204.htm (last visited Feb. 24, 2013, archived at $\mathrm{http}: / /$ perma.cc/TNE8-CQUU).

257. Claire Andre \& Manuel Velasquez, Creating the Good Society, 5 Issues IN ETHICS (1992), archived at http://perma.cc/E2MT-3WQZ (citing ROBERT N. BELLAH ET AL., THE Good Society (New York: Alfred A. Knopf, Inc., 1991)). Americans have long-standing allegiance to individualism. Id. This is the belief that Americans can pursue their desires independently of others. $I d$.

258. The Declaration of IndePendence paras. 4-5 (U.S. 1776). 
constitution, statutes, and government, albeit subject to a federal Constitution and government, makes the value systems throughout the country varied. Thailand has a monarchy, federal executive branch, and provincial and more localized leaders, and the law throughout the land is decided on a federal level. ${ }^{259}$ People of the United States have richly diverse religious, political, social, and ideological beliefs. ${ }^{260}$ Thailand has a strong collective conscience rooted in Buddhist principles ${ }^{261}$ and an unmatched adoration of the monarchy_-particularly the king. ${ }^{262}$ Yet complete abiding of lèse-majesté laws and continued reverence of the monarchy are not mutually exclusive. The "red shirts" party in Thailand has long been opposed to the law; scholars have come together to urge changes to it, ${ }^{263}$ and hundreds of charges and convictions indicate that this country's people are not submitting in complacency to the draconian law. Thai people do not need to be on their knees to love the king and the Kingdom.

State solidarity chants "Long live the King," "God save the Queen," and other wishes for monarchical longevity. ${ }^{264}$ When a crown ruler dies (at least in a hereditary monarchy), familial lineage is usually set for transition. ${ }^{265}$ Here lies another hurdle for free speech reform in Thailand: unlike potentially drastic differences in political ideologies based on new party leadership in the United States, the monarch as leader of a state, ruling through familial lineage, may not open a dialogue for meaningful change for some time - if at all. However, to be effective, laws preserving the honor of that royal blood should not perplex the governmental agencies that enforce those laws. Likewise, free speech freedoms depend on

259. Thai Governmental Structure, THAILAND LAW ForUM, http://www.thailawforum.com/articles/briggsgov.html (last visited March 1, 2013, archived at http://perma.cc/E4HC-MNNM).

260. Report: Diversity Growing in Nearly Every State, NBC NEws, http://www.nbcnews.com/id/14348539/\#.UTzzKRyLZmw (last updated Aug. 17, 2006, 5:12 PM, archived at http://perma.cc/4XWA-KPNR).

261. Duncan McCargo, Buddhism, Democracy and Identity in Thailand, 11 DemocratiZATION 155, 156 (2004), archived at http://perma.cc/UR4G-XSU9.

262. Jonathan Head, Why Thailand's King is So Revered, BBC News (Dec. 5, 2007), http://news.bbc.co.uk/2/hi/asia-pacific/7128935.stm, archived at http://perma.cc/T6BSV2SB.

263. Mong Palatino, Reform the World's Harshest Lèse-Majesté Law, GLOBALVoiceS (Feb. 12, 2012), http://globalvoicesonline.org/2012/02/12/thailand-reform-the-worldsharshest-lese-majeste-law/, archived at http://perma.cc/SFP3-Z2SF.

264. Long Live the King, BANGKOK POST (Dec. 5, 2012), http://www.bangkokpost.com/learning/learning-from-news/324686/long-live-the-king, archived at http://perma.cc/6LYW-P3XN. After the King's 85th birthday speech and the Thai national anthem, the crowd of 200,000 roared "Song Phra Chareon, Song Phra Chareon," meaning, "Long live the King." Id.

265. Hereditary Monarchy, WIKIA, http://micronations.wikia.com/wiki/Hereditary_monarchy (last visited Feb. 12, 2013, archived at http://perma.cc/7UW9-Q55R). 
governmental bodies such as the judiciary for persistent enforcement. Therefore, whether speech laws are inhibiting or empowering in nature, their effectiveness depends partly on clearly defined practical limitations that serve a governmental or civil purpose.

Lack of such limitations is partly what makes Thai lèse-majesté laws questionable. The Amornvivat case showed the practical failure of Thai lèse-majesté law lending to its over breadth and far reach. ${ }^{266}$ The same body that gave vitality to the law - the police - was apprehended for lèse-majesté simply because it followed custom in publishing the crime in the official government periodical. $^{267}$ Several officers, including the police chief, a lawyer, and the king himself were involved in the convoluted charges. ${ }^{268}$ Thai lèse-majesté law in its current form and recent enforcement procedures are counter-productive. Even if they were to restrict publication and other avenues of publicizing its enforcement, it would lose the communicative component of deterrence.

The audacity of the Occupy Wall Street movement was created by the contagion of public awareness in city centers. ${ }^{269}$ The public outcry element of First Amendment free speech freedoms rang loud and clear through the nation; however, there were sensible, practical limitations for the movement. ${ }^{270}$ No question, the courts could not overrule the right of the American people to rally, but occupation of rally points overnight would impede the same unit that has the power to propel the change protesters demanded, namely, the government. ${ }^{271}$ First Amendment freedoms are broad. ${ }^{272}$ Any number of public issues can be raised by countless modes of expression without legal consequence. ${ }^{273}$ Yet the US judiciary realizes that proper functioning of those freedoms requires limitations aimed at societal stability. ${ }^{274}$ Unless Thai lèse-majesté laws are similarly narrowed in scope and applicability — or better yet, repealed - they will produce absurd and counterproductive results like those in Amornvivat. ${ }^{275}$

Speech-related laws are further impracticable when enforced upon

266. Streckfuss, supra note 1, at 461 .

267. Streckfuss, supra note 1 , at 461.

268. Streckfuss, supra note 1, at 461-62.

269. Kuntsler, supra note 181, at 990.

270. Kuntsler, supra note 181, at 992.

271. Kuntsler, supra note 181, at 992.

272. Scott F. Uhler \& Rinda Y. Allison, Libraries and the Internet, Part II: Legally Speaking, What is the Internet?, IlL. PERIODICALS ONLINE, http://www.lib.niu.edu/1998/1980111.html (last visited Feb. 1, 2013, archived at http://perma.cc/C5DN-GQQ7).

273. Ken Paulson, Not Many Exceptions to Free Speech Guarantee, First AmENDMENT CENTER (Nov. 18, 2011), http://www.firstamendmentcenter.org/not-many-exceptions-tofree-speech-guarantee, archived at http://perma.cc/BKN4-HRQW.

274. See, e.g., Kuntsler, supra note 181 , at 990.

275. Struckfuss, supra note 1 , at 461 . 
technological spheres. The case of "Uncle SMS" gave an unsettling and uproarious hint that an unprecedented amount of lèse-majesté charges, spanning phone, internet, TV, and more, could potentially be borne. ${ }^{276}$ The accused's claim of not sending those messages, ${ }^{277}$ regardless of the claim's veracity, provokes the concern that any Thai person could be wrongfully accused if his or her name is included in a technological medium that insults the monarchy. "Don't leave your Facebook unattended!"278 Indeed, the Thai government has given a warning that simply "liking" a Facebook post could be means for a lèse-majesté violation. ${ }^{279}$

First Amendment protections are properly secured against technological limitations as seen in Reno. ${ }^{280}$ Child protection laws are some of the strictest in the United States, often limiting free speech despite First Amendment freedoms. ${ }^{281}$ But Reno exemplified that legal strongholds on communication mediums of such vast reach are impracticable and would choke the power of the internet and other mediums to proliferate information among people. ${ }^{282}$ With more people logging on to the web and sending a text message instead of making a call in Thailand and worldwide, Thai lèse-majesté laws' jurisdiction over the airwaves could mean increased use of police resources for what are often innocuous threats to national security.

\section{B. What Do You Have Left to Say?}

The potential repeal of Thai lèse-majesté laws leaves much to question about which laws, if any, should remain to protect the monarchy from legitimate threats of national security due to potentially dangerous speech. It is reasonable for laws controlling physical threats to the monarchy to be in place. Moreover, Thailand has considerably strict defamation laws that apply to all citizens, ${ }^{283}$ so the goal of a smooth transition from repeal of the stricter lèse-majesté laws would warrant the

276. An Inconvenient Death, supra note 149.

277. An Inconvenient Death, supra note 149.

278. This is a reference to the warning given by Facebook users to other users to not leave their Facebook account logged on as to avoid hijacking in the form of embarrassing status updates by hijackers.

279. Lese Majeste Warning for Facebook, BAngKoK Post (Nov. 24, 2011, 6:02 PM), http://www.bangkokpost.com/breakingnews/267732/facebook-like-button-may-bring-lesemajeste-charge-against-users, archived at http://perma.cc/9Q7V-DBYK.

280. Reno v. ACLU, 521 U.S. 844, 849 (1997).

281. Bill Mears, Justices: Child Porn Is Not Protected Speech, CNN, http://www.cnn.com/2008/CRIME/05/19/scotus.porn/index.html (last updated May 19, 2008, archived at http://perma.cc/9XQW-T39K).

282. Reno, 521 U.S. at 849.

283. CRIM. C., B.E. 2499 (1956), ss. 327-28, amended by CRIM. C. (No. 17), B.E. 2547 (2003) (Thai.). 
monarchy's protection under the existing defamation laws. Notably, defamation laws enforce jail time of not more than two years instead of the fifteen one could suffer if she insulted the monarchy. ${ }^{284}$ The following are two of the provisions of Thai defamation law:

Whoever, imputing anything the [sic] deceased person before the third person, and that imputation to be likely to impair the reputation of the father, mother, spouse or child of the deceased or to expose that person hated or scammed to be said to commit defamation, and shall be punished as prescribed by Section 326 .

If the offence of defamation be committed by means of publication of a document, drawing, painting, cinematography film, picture or letters made

visible by any means, gramophone record or another recording instruments, recording picture or letters, or by broadcasting or spreading picture, or by propagation by any other means, the offender shall be punis hed with imprisonment not exceeding two years and fined not exceeding two hundred thousand Baht. ${ }^{285}$

A challenge for this Note's recommendation is that total and instantaneous repeal of lèse-majesté laws may produce a legitimate threat to national security-which is the apparent public policy reason for the laws. ${ }^{286}$ People who have long inhibited passionate criticism of the monarchy may come together in floods of uproar to demand change. Violence may break out in the streets as police clash with citizens. Again, one recalls the Arab Spring and the violent challenges that accompany marked change in a country's political structure. ${ }^{287}$ Therefore, this Note recommends, as a means of sound transition, that a provision be added to current defamation laws specially protecting the monarchy from defamation. This would limit police determinations of a threat to reputation, or false accusations, required for a finding of unlawful speech against the monarchy. This way, for example, scholars could publish legitimate, peerreviewed work criticizing the monarchy. ${ }^{288}$ Respectable criticism with noble

284. Id.

285. Id.

286. The provision on lèse-majesté is listed under the Book II - Title I "Offenses Relating to the Security of the Kingdom.

287. Yoel Guzansky, The Arab Spring's Violent Turn, NAT'L InTEREST (Dec. 15, 2011), http://nationalinterest.org/commentary/the-arab-springs-violent-turn-6254, archived at http://perma.cc/5PEG-UMU6.

288. For example, academic articles that cite references to the facts that make up arguments would inherently be based on a factual structure, leaving little doubt, holding academic integrity constant, as to whether the points are fallacious such as to invoke 
tone would avoid defamation accusations because it would not necessarily be malicious. The antithesis to this proposal is that special treatment for the monarchy in defamation laws may be abused to silence critics just as lèsemajesté laws have; however, repeal of lèse-majesté itself could only happen if the government made a conclusive decision to welcome criticism. Thus, chances of the same free speech abuses would be lessened. Also, the twoyear limit of incarceration for defamation, against the possible fifteen years for lèse-majesté, limits the abuse Thai authority could inject into the citizenry's fundamental right to free speech and expression.

This Note encourages further thought and research into the hopeful post-lèse-majesté era in Thailand. With the arguments and case timelines presented in this Note as one possible starting point, ideas should be generated as to how the revered status of the monarchy in Thailand can maintain some justified protection while granting the Thai people a voice to criticize the crown as the current king has welcomed. ${ }^{289}$ These ideas should consider factors including, but not limited to: national security, defamation, Buddhism, the Arab Spring, technological advancements, the possibility of a new king in light of the current king's health, and the military and political landscape of Thailand.

\section{CONCLUSION}

American abolitionist, Frederick Douglass, once said, "[T] free speech is a double wrong. It violates the rights of the hearer as well as those of the speaker." 290 This is perhaps the essence of the First Amendment of the US Constitution. It is also probably why the current Thai king welcomed self-criticism, for arguably a benevolent king wants to know how his subjects feel about his rule. ${ }^{291}$ Thai lèse-majesté law must go. Thailand is the only nation that still strictly enforces a law that has only ancient appeal. ${ }^{292}$ Today, there is robust outcry from the people of the world for more transparency, less fascism and despotism, and more say in governmental decisions. ${ }^{293}$ The internet is a beacon for the masses to use the sheer force of numbers to stand up to concentrated political power, and Thailand should not distinguish itself as a muzzle for those that question the power and sway of the monarchy via the internet.

The First Amendment stands in stark contrast to the restrictions imposed by Thai lèse-majesté law, and the values and legal practicality of the application of First Amendment freedoms should serve as a model for a

\footnotetext{
defamation.

289. Birthday Speech, supra note 154 .

290. Frederick Douglass, A Plea for Free Speech in Boston (1860), archived at http://perma.cc/R2C2-ZYD7.

291. Birthday Speech, supra note 154.

292. Pitman \& Tunsarawuth, supra note 4.

293. See generally The Arab Spring: A Year of Revolution, supra note 238.
} 
shift in Thai free speech laws. Granted, a constitutional monarchy is fundamentally different from a federal presidential constitutional republic, ${ }^{294}$ and Thailand cannot be expected to open up to speech of all sorts overnight. However, there is a positive, liberating spirit to the First Amendment, and a disturbing, quieting effect to lèse-majesté laws that beg legal reform when the two are juxtaposed. It is time to silence the silenceThai lèse-majesté laws ought to be repealed.

294. A constitutional monarchy has a king or queen as the head of state and a parliament to make laws. What is Constitutional Monarchy, OfFicial Website of thE BRITISH MONARCHY,

http://www.royal.gov.uk/monarchuk/howthemonarchyworks/whatisconstitutionalmonarchy.a spx (last visited Feb. 24, 2013, archived at http://perma.cc/CFX5-ATMC). A constitutional republic's heads of state are the people, represented by a government elected by the people. Mathew Fulton, What is a Constitutional Republic, HeLIUM, http://www.helium.com/items/1960135-constitutional-republic (last visited Feb. 24, 2013, archived at http://perma.cc/L9XM-Q7KJ). 